\title{
MENINGKATKAN PROFESIONALISME GURU KELAS I DAN \\ II MELALUI OPTIMALISASI PELAKSANAAN SUPERVISI AKADEMIK DI GUGUS NAKULA V KECAMATAN SERENGAN KOTA SURAKARTA
}

\author{
Ismiyatun \\ UPTD Dikpora Kecamatan Laweyan Surakarta \\ ismiyatun2016@gmail.com
}

\begin{abstract}
This research aimed at increasing the teacher's ability in making a lesson plan and conducting a learning process in the class. Type of this research is an Action Research. This research was conducted in 5 school areas of Gugus V Nakula of Serengan Subdistrict, Surakarta. The location selection of this research was because the schools are under the guidance of the researcher, because from the results of observation, there were still many teachers who had not understood the main task and functions of a professional teacher. This research was conducted for three months from July 2011 to September 2011, starting from the preparation up to the reporting. Basically, the data which became the analysis materials were primary data that were through a direct observation obtained from the respondents by using the Instrument of Observation. The data consisted of data on the teachers'ability in composing a syllabus and lesson plan (RPP), as well as implementing a learning in the class. The results of the research conclusion and discussion were as follows: 1) The giving of guidance in the beginning of composing the syllabus, the lesson plan, and the implementation of learning can optimize the results of supervision that was increasing the teachers' professionalism. It could be viewed from the increase in the teachers' ability from the early condition, cycle I and cycle II based on the data obtained by the researcher; 2) The Academic Supervision could increase the teachers' ability in becoming professional teachers. From 13 teachers who became the researcher' partners, their professional ability was increased significantly. In composing the lesson plan in the cycle I, from 13 teachers, all of them (100\%) obtained scores under 90. Nevertheless, in cycle II, the scores of all teachers increased, therefore, only one teacher whose score was under 90 (7.69\%). Similarly, in their ability of implementing the learning, in cycle I, only 2 teachers whose scores were above 80 (15\%). Nevertheless, in cycle II, the teachers'scores increased totally, only one teacher whose score was under 90.
\end{abstract}

Keywords: teacher's professionalism, optimalization, academic supervision

\section{ABSTRAK}

Penelitian ini bertujuan untuk meningkatkan kemampuan guru dalam membuat perencanaan pembelajaran dan melaksanakan proses pembelajaran di kelas. Jenis 
penelitiannya adalah Penelitian Tindakan. Penelitian ini dilakukan di 5 sekolah wilayah gugus V Nakula Kecamatan Serengan Surakarta, pemilihan lokasi penelitian ini, karena sekolah tersebut merupakan sekolah binaan saya, karena dari hasil pengamatan masih banyak guru yang belum memahami tugas pokok dan fungsi sebagai guru Profesional. Penelitian ini dilakukan 3 bulan dari bulan Juli 2011 samapai dengan bulan September 2011 mulai dari persiapan sampai dengan pelaporan. Pada dasarnya data yang menjadi bahan analisis adalah data primer yaitudengan pengamatan langsung yang di peroleh dari responden dengan menggunakan Intrumen Pengamatan. Data-data tersebut adalah data kemampuan guru dalam menyusun Silabus, RPP, serta Pelaksanaan Pembelajaran di Kelas. Hasil kseimpulan penelitian dan pembahasan adalah sebagai berikut: 1) Pemberian bimbingan di awal penyusunan Silabus, RPP, dan pelaksanaan Pembelajaran dapat mengoptimalkan hasil supervisi yaitumeningkatkan Propesionalisme guru. Hal ini dapat dilihat dari peningkatan kemampuan guru dari keadaan awal, siklus I, dan siklus II berdasarkan data yang diperoleh peneliti; 2) Supervisi Akademik dapat meningkatkan kemampuan guru untuk menjadi guru yang profesional. Dari 13 guru yang menjadi mitra peneliti kemampuan profesionalnya terlihat meningkat secara berarti. Dalam menyusun RPP pada siklus I dari 13 guru, seluruhnya (100\%) memperoleh nilai dibawah 90. Namun pada siklus II nilai semua guru meningkat sehingga tinggal 1 orang guru yang nilainya dibawah 90 (7,69\%). Demikian juga pada kemampuan pelaksanaan pembelajaran, pada siklus I hanya 2 orang guru yang nilainya di atas 80 (15\%). Namun pada sikuls II nilai guru meningkat secara keseluruhan, tinggal 1 orang guru yang nilainya dibawah 90 .

Kata kunci: profesionalisme guru, optimalisasi, supervisi akademik

\section{PENDAHULUAN}

Undang-Undang RI Nomor 20/2003 tentang Sistem Pendidikan Nasional, Undangundang RI Nomor 14/2005 tentang Guru dan Dosen, dan Peraturan Pemerintah RI Nomor 19/2005 tentang Standar Nasional Pendidikan menyatakan guru adalah pendidik profesional. Untuk itu, guru dipersyaratkan menguasai kompetensi sebagai agen pembelajaran. Salah satu kompetensi guru sebagai agen pembelajaran adalah kompetensi propesional. Guru dikatakan propesional apabila memiliki kemampuan dan memahami tugas pokok dan fungsi sebagai guru dan dapat melakukan inovasi-inovasi sehingga proses pembelajaran disekolah menyenangkan bagi pesrta didik. Namun, kenyataan disekolah yang saya pimpin menunjukkan bahwa masih banyak guru/tenaga pendidik yang belum memahami makna kepropesionalismeannya sebagi guru yang sesuai dengan undang-undang dan peraturan pemerintah sebagaimana dijelaskan diatas,ketidak profesionalismean itu terlihat dari sebagian besar guru belum mampu mengembangkan kemampuan mengelola proses pembelajaran untuk mencapai tujuan pembelajaran yang diharapkan .

Untuk mengatasi masalah tersebut diatas perlu dilaksanakan tindakan nyata oleh pimpinan sekolah dalam bentuk supervisi, hal ini sesuai denganpermendiknas nomor 13 Tahun 2007, bahwa salah satu kompetensi kepala sekolah adalah kompetensi supervisi. Dalam hal ini 
kepala sekolah harus dapat merencanakan, melaksanakan dan menindaklanjuti hasil supervisi akademik dalam rangka meningkatkan profesionalisme guru yang pada gilirannya akan dapat meningkatkan kualitas pembelajaran. Merencanakan bearti bahwa kepala sekolah harus menyusun program supervisi akademik agar suprvisi yang dilakukan menacapai tujuan dan sasarannya secara efektif dan efisien. Melaksanakan supervisi berarti kepala skolah harus menggunakan pendekatan dan teknik supervisi dengan tepat. Menindaklanjuti berarti bahwa kepala sekolah dapat memanfaatkan hasil supervisi dalam rangka memperbaiki penyimpangan yang terjadi agar pelaksanaan tugas akan lebih baik.

Pentingnya pelaksanaan supervisi oleh kepala sekolah karena semua kegiatan yang ada di sekolah merupakan tanggung jawab kepala sekolah. Guna mencapai tujuan institusi, kepala sekolah mendelegasikan tugas kepada guru dan staf. Oleh karena itu perlu dipastikan bahwa tugas yang didelegasikan telah dilaksanakan pada waktu dan cara yang tepat, sesuai dengan standar, dan jika perlu melakukan langkah-langkah perbaikan. Demikian juga dengan pembelajaran, kepala sekolah perlu memastikan bahwa proses belajar mengajar berjalan lancar sesuai dengan tuntutan kurikulum. Untuk itu kepala sekolah perlu melakukan supervisi akademik. Ari latar belakang diatas, maka tujuan penelitian ini adalah untuk meningkatkan kemampuan guru dalam membuat perencanaan pembelajaran dan melaksanakan proses pembelajaran di kelas.

\section{METODE}

Subjek penelitian ini adalah Guru Kelas Idan II yang bertugas mengajar di sekolah wilayah gugus V Nakula Kecamatan Serengan Surakarta yang berjumlah 13 orang. Penelitian ini dilakukan di 5 sekolah wilayah gugus V Nakula Kecamatan Serengan Surakarta, pemilihan lokasi penelitian ini, karena sekolah tersebut merupakan sekolah binaan saya, karena dari hasil pengamatan masih banyak guru yang belum memahami tugas pokok dan fungsi sebagai guru Profesional. Penelitian ini dilakukan 3 bulan dari bulan Juli 2011 samapai dengan bulan September 2011 mulai dari persiapan sampai dengan pelaporan.

Penelitian ini dilakukan dalam dua siklus, dimana kegiatan untuk masing-masing siklus terdiri adalahPerencanaan,Pelaksanaan, Pengamatan/observasi, Evaluasi/Refleksi. Adapun tahap-tahap kegiatan penelitian setiap siklusnya adalah sebagai berikut: a) Perencanaan; b) Pelaksanaan; Pengamatan; Refleksi dan Evaluasi.

\section{HASIL DAN PEMBAHASAN}

Dari hal-hal yang menjadi permasalahan pada penelitian, maka hasil pengamatan yang dilakukan pada penelitian ini dapat disajikan ke dalam grafik sebagai berikut yaitu : 


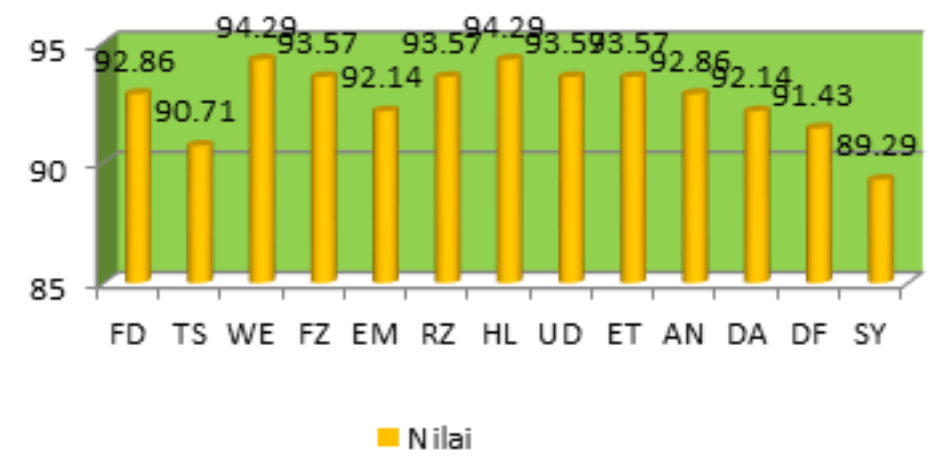

Gambar 1: Kemampuan Guru dalam Mengembangkan Silabus:

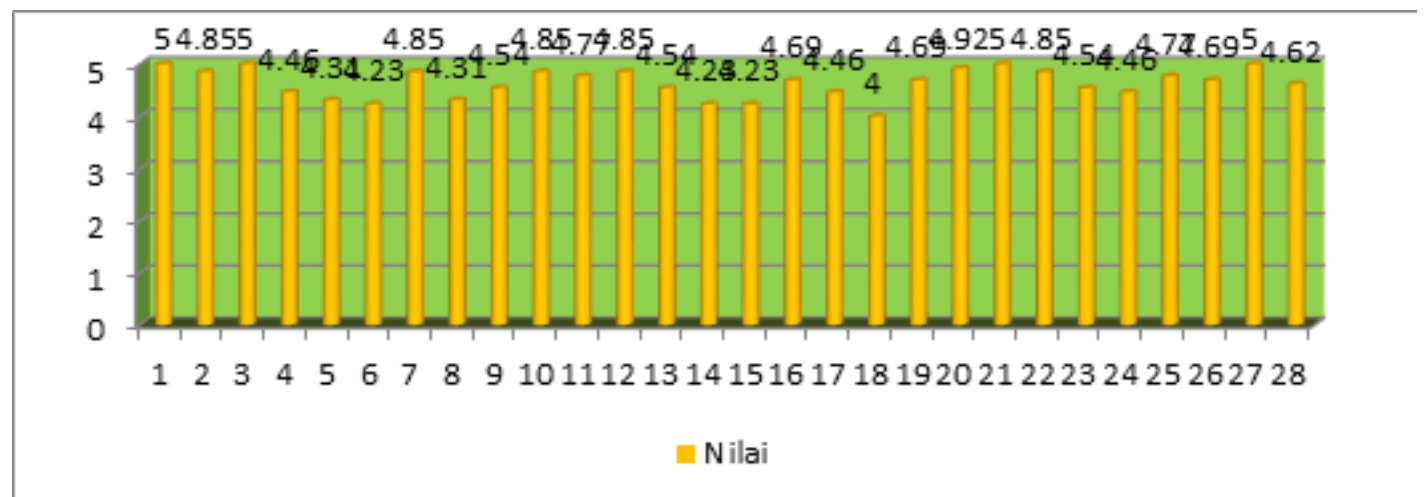

Gambar 2. Kemampuan Guru dalam Mengembangkan Silabus menurut Indikator

Sedangkan hasil pengumpulan data menggunakan intrumen AK-02 terdapat beberapa variasi data. Dari data nilai yang diperoleh masing-masing guru terendah adalah 70,4 dan tertinggi 86,4. Memang tidak ada yang mencapai nilai 90 atau lebih namun hasilnya tidaklah mengecewakan.

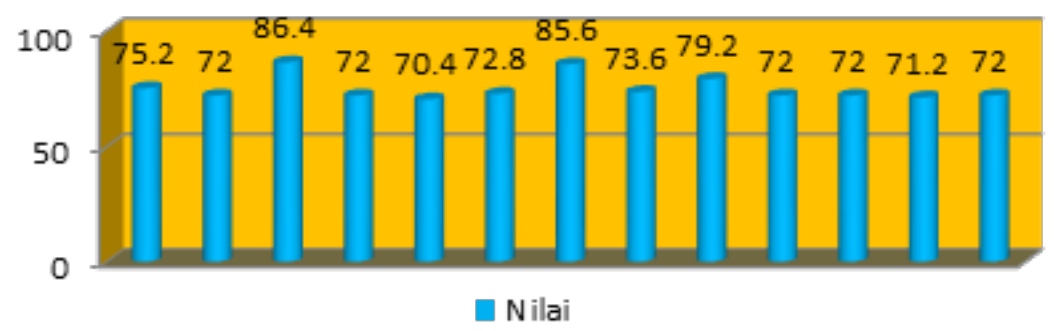

Gambar 3. Kemampuan Guru dalam Menyusun RPP: 


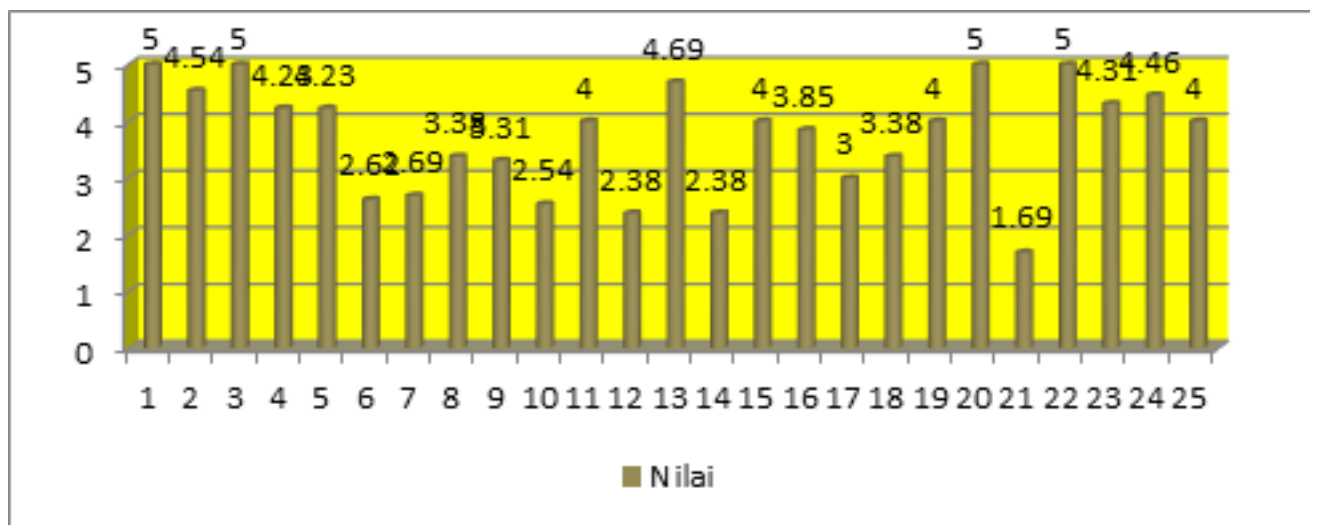

Tabel 4: Kemampuan Guru dalam Menyusun RPP menurut Indikator:

1. Pada RPP

a. Memilih metode pembelajaran yang relevan dengan tujuan dan materi pembelajaran. Guru kesulitan menentukan metode yang relevan dan sesuai dengan tujuan yang ingin dicapai. Metode mengajar yang dirancang hanya metoda tanya jawab.

b. Menentukan metode pembelajaran yang bervariasi. Akibat dari ketidakmampuan guru memili metode mengajar yang relevan dengan tujuan dan karakteristik materi pembelajaran, maka metode mengajar yang dirancang tidak bervariasi.

c. Menentukan cara cara memotivasi siswa. Guru tidak memberikan soal tantangan, atau menginformasikan penggunaan materi yang diajarkan dalam kehidupan sehari hari yang kesemuah itu merupan bentuk bentuk memotivasi siswa dalam pembelajaran.

d. Menyusun langkah langkah mengajar. Secara umum guru membuat langkah langkah mengajar tetapi kurang operasional dan tidak rinci.

e. Menentukan cara cara pengorganisasian siswa agar dapat berpartisifasi aktif dalam KBM. Sebahagian besar Guru tidak merancang cara cara pengorganisasian siswa agara selalu berperan aktif dalam KBM.

f. Menentukan prosedur dan jenis penilaian. Pada umumnya guru membuat soal untuk evaluasi tetapi tidak dilengkapi dengan kunci jawaban dan pedoman penskoran.

2. Pada Pelaksanaan Pembelajaran yaitu :

a. Pada kegiatan awal, guru tidak melakukan motivasi terhadap siswa, seperti memberikan soal tantangan, menyampaikan tujuan pengajaran, akibatnya konsentrasi siswa pada awal awal pengajaran tidak fokus bahkan guru mengajar seakan tidak diperhatikan siswa

b. Pada kegiatan inti ada beberapa kelemahan yang terjadi yaitu :

1) Penggunaan metode pengajaran yang bervariasi. Dalam mengajar guru terfokus hanya pada penggunaan metode mengajar tanya jawab, tidak bervariasi, tidak memperhatikan karakteristik materi ajar dan kemampuan siswa.

2) kelemahan guru dalam mengorganisasikan siswa dalam belajar. Secara umum 
mereka mengkondisikan siswa secara klasikal sehingga kurang memberikan hasil yang maksimal terhadap hasil pembelajaran.

3) Guru tidak melaksanakan penilaian selama proses berlansung, sehingga kesulitan belajar yang dialami siswa tidak diketahui dan tak bisa diatasi ketika proses pembelajaran berlangsung.

Setelah dilakukan perlakuan/bimbingan kepada guru diperoleh hasil sebagai berikut:

\section{Pada RPP}

a. Dalam memilih metode pembelajaran yang relevan dengan tujuan dan materi pembelajaran. pada siklus I kebanyakan guru terfokus pada penggunaan metode tanya jawab dan pada siklus II guru telah membuat metode yang relevan, sesuai dengan tujuan dan materi pembelajaran. Dari 9 orang yang bermasalah pada siklus I, pada siklus II tidak ditemukan lagi.

b. Menentukan metode yang bervariasi, pada siklus I kebanyakan guru terfokus pada penggunaan metode tanya jawab dan pada siklus II guru telah membuat metode yang bervariasi. Dari 9 orang yang bermasalah pada siklus I, pada siklus tinggal 2 orang.

c. Dalam menentukan cara cara memotivasi siswa, pada siklus I masih menjadi masalah oleh sebahagian besar guru, dan pada siklus II sudah mengalami perbaikan. Dari 11 orang yang bermasalah pada siklus I, tinggal 1 orang pada siklus II

d. Menyusun langkah langkah mengajar, pada siklus I langkah langkah mengajar dibuat tidak rinci, namun pada siklus II dibuat secara rinci dan mudah dipedomani. Dari 10 orang yang dianggap bermasalah pada siklus I, pada siklus II tidak ditemukan lagi.

e. Dalam pengorganisasian siswa yang dalam pembelajaran pada siklus I masih menjadi masalah bagi sebagian guru, dan pada siklus II sudah mengalami perbaikan. Dari 11 orang yang bermasalah pada siklus I tinggal 1 orang pada siklus II.

f. Menentukan prosedur dan jenis penilaian, pada siklus I sebahagian besar guru tidak membuat prosedur dan jenis penilaian. Pada siklus II guru telah membuat kunci jawaban dan pedoman penskoran untuk bidang studi eksak atau kriteria jawaban dan pedoman penskoran untuk bidang studi sosial. Dari 10 orang yang bermasalah pada siklus I, pada siklus II semua guru telah membuat secara lengkap.

2. Pada pelaksanaan pembelajaran

a. Guru tidak melakukan motivasi terhadap siswa, seperti memberikan soal tantangan, menyampaikan tujuan pengajaran dan lain lain. Pada siklus I hanya sebahagian kecil guru yang melakukannya, namun pada siklus II guru telah melakukan motivasi sebelum pembelajaran dimulai. Dari 11 orang yang bermasalah pada siklus I, tinggal 1 orang pada siklus II

b. Penggunaan metode pengajaran yang bervariasi. Pada siklus I semua guru melakukan pengajaran dengan menggunakan metode tanya jawab tanpa memperhatikan ke- 
mampuan siswa, tetapi pada siklus II guru telah memvariasikan metode mengajarnya sehingga PBM lebih menyenangkan. Dari 11 orang yang bermasalah pada siklius I, tinggal 2 orang pada siklus II.

c. Mengorganisasikan siswa dalam belajar. Pada siklus I sebahagian besar guru mengajar secara klasikal, tetapi pada siklus II seiring dengan variasi metode mengajar yang digunakan guru, siswa dikelompokan dalam kelompok kelompok kecil sehingga siswa terlihat bebas bertanya pada teman sejawat. Dari 10 orang yang bermasalah pada siklus I, tinggal 1 orang pada siklus II.

d. Guru tidak melaksanakan penilaian selama proses berlansung. Pada siklus I guru fokus memperhatikan siswa yang pandai kesulitan belajar yang dialami sebahagian besar siswa tidak diketahui karena guru tidak berkeliling memberikan bantuan kepada siswa yang mengalami kesulitan. Pada siklus II guru berkeliling memberikan bantuan seperlunya sehingga kesulitan belajar yang dialami siswa dapat diatasi. Pada siklus I ada 10 orang guru yang bermasalah, dan pada siklus II tinggal 1 orang.

Berdasarkan data tersebut dan pengamatan, peneliti menyimpulkan bahwa pembelajaran yang dilakukan oleh guru telah sesuai dengan ketentuan yang digariskan pemerintah yaitu sesuai dengan Undang-Undang Republik Indonesia No. 20 Tahun 2003 tentang sistem Pendidikan Nasional pasal 39 ayat 2 yang menyebutkanPendidik merupakan tenaga profesional yang bertugas merencanakan danmelaksanakan proses pembelajaran, menilai hasil pembelajaran, melakukanpembimbingan dan pelatihan, serta melakukan penelitian dan pengabdian kepadamasyarakat, terutama bagi pendidik pada perguruan tinggi.Disisi lain peneliti dapat menyimpulkan bahwa pelaksanaan supervisi telah berhasil yaitu meningkatnya kemampuan guru dalam membuat perencanaan dan pelaksanaan pengajaranserta sesuai dengan apa yangdikemukakan oleh Oteng Sutisna (1989:265-266) bahwa peran supervisi merupakan bantuan profesional dan teknis kepada guru dengan maksud untuk meningkatkan kemampuan guru dan melalui itu meningkatkan kualitas pendidikan.

\section{SIMPULAN}

Kesimpulan dari hasil penelitian dan pembahasan adalah sebagai berikut:

1. Pemberian bimbingan di awal penyusunan Silabus, RPP, dan pelaksanaan Pembelajaran dapat mengoptimalkan hasil supervisi yaitumeningkatkan Propesionalisme guru. Hal ini dapat dilihat dari peningkatan kemampuan guru dari keadaan awal, siklus I, dan siklus II berdasarkan data yang diperoleh peneliti.

2. Supervisi Akademik dapat meningkatkan kemampuan guru untuk menjadi guru yang profesional. Dari 13 guru yang menjadi mitra peneliti kemampuan profesionalnya terlihat meningkat secara berarti. Dalam menyusun RPP pada siklus I dari 13 guru, seluruhnya (100\%) memperoleh nilai dibawah 90. Namun pada siklus II nilai semua guru meningkat sehingga tinggal 1 orang guru yang nilainya dibawah 90 (7,69\%). Demikian juga pada kemampuan pelaksanaan pembelajaran, pada siklus I hanya 2 orang guru yang nilainya 
di atas 80 (15\%). Namun pada sikuls II nilai guru meningkat secara keseluruhan, tinggal 1 orang guru yang nilainya dibawah 90 .

\section{DAFTAR PUSTAKA}

Adam \& Dickey, Basic Principles of Supervision, New York: American Book Company, 1959.

Arikunto, Suharsimi, Manajemen Pengajaran Secara Manusiawi, Jakarta: Rineka Cipta,1993. Azwar, Azrul, Pengantar Administrasi, Jakarta: P.T. Bumi Aksara, 1988.

Daryanto, H.M., Administrasi Pendidikan , Jakarta: Rineka Cipta, 1998.

Engkoswara, Dasar-dasar Manajemen Pendidikan, Jakarta Dirjen Dikti Depdikbud,1998.

Halsey, George D., Bagaimana Memimpin dan Mengawasai Pegawai Anda, Jakarta: Rineka Cipta,1994.

Nawawi, Hadari, Administrasi Pendidikan, Jakarta: Gunung Agung, 1984.

Pidarta, Made, Manajemen Pendidikan Indonesia Jakarta; Bina Aksara, 1998.

Purwanto, Ngalim, Administrasi dan Supervisi Pendidikan, Bandung:2005.

Pusdiklat Pegawai Depdiknas, Manajamen Sekolah, Depok: Depdiknas, 2007.

Suhertian, Piet, Konsep Dasar \& Teknik Supervisi Pendidikan, Jakarta: Rineka Cipta, 2000.

Sutisna, Oteng, Administrasi Pendidikan, Dasar Teoritis Untuk Praktek Profesional (Bandung: Angkasa, 1985 


\title{
PENGELOLAAN PENDIDIKAN KARAKTER BANGSA BERBASIS BUDAYA JAWA DI TK NEGERI PEMBINA SURAKARTA
}

\author{
Surani, Bambang Sumarjoko, dan Sabar Narimo \\ Program Studi Magister Administrasi Pendidikan \\ Email: surani329@gmail.com
}

\begin{abstract}
This study aimed to describe the character-based education management Javanese culture as well as enabling and inhibiting factors in TK Negeri Pembina Surakarta. This study uses qualitative research, research design using qualitative descriptive method. Implementation of this research is in the TK Negeri Pembina Surakarta. The data used in this study are primary data and secondary data. Source of the data obtained through interviews and documentation. As a guest speaker in this study was the Principal Teachers and Parents / guardians of students. The validity of the data used in this research is triangulation and source triangulation method. Data were analyzed using interactive analysis. Based on the results of data analysis and discussion we concluded that: 1) The management of education-based character of Javanese culture in TK Negeri Pembina Surakarta carried out by adjusting the curriculum and educational materials charged Javanese culture integrates the material elements of the arts, languages and social systems of Javanese culture, delivering materials charged the value of honesty, humility, discipline, courtesy, cooperation, caring, and responsibility; and deliver material which imparts the principles of respect, harmony, character wise and honest, introspective, low self-esteem, as well as upload formungguh and good manners as a form of character Java. 2) The supporting factors in the management of Javanese culture-based character education is education offices and local governments, provision of facilities, committee and parents of students, school management, as well as students coming from the Java community. Factors inhibiting Javanese culture-based education is the lack of standard guidelines for the implementation of educational programs that charged Javanese culture, interests learners to Javanese culture, as well as operate and circumstances on ignorance educators learn less supportive media to use.
\end{abstract}

Keywords: character education, java culture

\begin{abstract}
ABSTRAK
Penelitian ini bertujuan untuk mendeskripsikan pengelolaan pendidikan karakter berbasis budaya Jawa serta faktor pendukung dan penghambat di TK Negeri Pembina Surakarta. Penelitian ini menggunakan jenis penelitian kualitatif, desain penelitian menggunakan metode deskriptif kualitatif. Pelaksanaan penelitian ini adalah di TK Negeri Pembina Surakarta. Data yang digunakan dalam penelitian ini
\end{abstract}


adalah data primer dan data sekunder. Sumber data diperoleh melalui wawancara dan dokumentasi. Sebagai narasumber dalam penelitian ini adalah Kepala Sekolah Guru dan Orang tua / wali siswa. Validitas data yang digunakan dalam penelitian ini adalah triangulasi metode dan triangulasi sumber. Teknik analisis data menggunakan analisis interaktif. Berdasarkan hasil analisis data dan pembahasan diperoleh kesimpulan bahwa: 1) Pengelolaan pendidikan karakter berbasis budaya Jawa di TK Negeri Pembina Surakarta dilaksanakan dengan menyesuaikan pada kurikulum dan materi pendidikan yang bermuatan budaya Jawa mengintegrasikan materi unsur seni, bahasa dan sistem sosial budaya Jawa, menyampaikan materi bermuatan nilai kejujuran, kerendahan hati, kedisiplinan, kesopanan, kerja sama, kepedulian, dan tanggung jawab; dan menyampaikan materi yang menanamkan prinsip hormat, kerukunan hidup, watak arif dan jujur, mawas diri, rendah diri, serta membentuk unggah-ungguh dan tata krama yang baik sebagai wujud budi pekerti Jawa. 2) Faktor pendukung dalam pengelolaan pendidikan karakter berbasis budaya Jawa yaitu dinas pendidikan dan pemerintah daerah, penyediaan fasilitas, komite dan orang tua peserta didik, managemen sekolah, serta peserta didik berasal dari masyarakat Jawa. Faktor penghambat pendidikan berbasis budaya Jawa yaitu belum adanya pedoman baku untuk pelaksanaan program pendidikan yang bermuatan budaya Jawa, minat peserta didik terhadap budaya Jawa, serta kekurangtahuan pendidik mengoperasikan maupun keadaan media belajar yang kurang mendukung untuk digunakan.

Kata Kunci: pendidikan karakter, budaya jawa

\section{PENDAHULUAN}

Membicarakan karakter merupakan hal sangat penting dan mendasar. Orang-orang yang berkarakter kuat dan baik secara individual maupun sosial ialah mereka yang memiliki akhlaq, moral, dan budi pekerti yang baik. Mengingat begitu pentingnya karakter, maka institusi pendidikan memiliki tanggung jawab untuk menanamkannya dalam diri peserta didiknya. Pendidikan karakter dimaknai sebagai suatu perilaku yang di dalam penyelenggaraan pendidikan harus berkarakter dan berpijak dari karakter dasar manusia dari nilai moral yang bersumber dari agama dan dengan sadar mau melaksanakan nilai-nilai tersebut, baik terhadap Tuhan Yang Maha Esa (YME), diri sendiri, sesama, lingkungan, maupun kebangsaan sehingga menjadi insan kamil. Dalam pendidikan karakter di sekolah, semua komponen (stakeholders) harus dilibatkan, termasuk komponen-komponen pendidikan itu sendiri, yaitu isi kurikulum, proses pembelajaran, penilaian, kualitas hubungan, pengelolaan mata pelajaran, sekolah, aktivitas atau kegiatan ekstrakurikuler, pemberdayaan sarana prasarana, pembiayaan, dan etos kerja seluruh warga dan lingkungan sekolah.

Megawangi (2012: 33) mencontohkan bagaimana kesuksesan Cina dalam menerapkan pendidikan karakter sejak awal tahun 1980-an. Menurutnya, pendidikan karakter adalah untuk mengukir akhlak melalui proses knowing the good, loving the good, and acting the good. Yakni, suatu proses pendidikan yang melibatkan aspek kognitif, emosi, dan fisik, sehingga akhlak mulia bisa terukir menjadi habit of the mind, heart, and hands. "Belajar di masa 
kecil ibarat mengukir diatas batu, sedangkan belajar ketika sudah dewasa ibarat mengukir di atas air". Istilah tersbut sangat populer dan memiliki makna yang dalam. istilah tersebut juga mempunyai makna yang sesuai dengan konsep pendidikan anak usia dini yang sangat mementingkan stimulasi sejak dini agar anak dapat belajar banyak dan mengembangkan potensi dan minat yang dimiliki anak yang akan memberikan pengalaman dan kenangan yang begitu kuat terhadap anak, hal ini sangat berbeda ketika kita sudah dewasa apalagi kita menyinggung tentang karakter dan watak yang sudah menjadi kesatuan dalam kepribadian sehingga untuk merubahnya akan jauh lebih sulit. Sehingga penanaman karakter sejak dini menjadi kunci utama dalam membentuk karakter positif anak dan menjadi pondasi kepribadian yang akan menjadi orang yang memiliki karakter kuat.

Pendidikan karakter dapat diintegrasikan pada setiap materi yang disampaikan dalam metode pembelajaran yang ada di tingkat Taman Kanak-Kanak yang meliputi sekurangkurangnya 3 hal yaitu : Pertama Afektif, yang tercermin dalam kualitas keimanan, ketakwaan, akhlaq mulia termasuk budi pekerti luhur serta berkepribadiaan unggul, dan kompetensi estestis. Kedua Kognitif, yang tercermin kepada kwalitas fikir, dan daya intelektualitas untuk menggali dan mengembangkan serta menguasai ilmu pengetahuan dan tekhnologi tentu saja yang berdasar kepada pendidikan nilai, norma dan akhlaq sebagai landasan pendidika karakter. Ketiga Psikomotorik, yang tercermin kepada kemampuan mengembangkan ketrampilan tekhnis, kecakapan praktis, dan kompetensi kinestetis.

Pendidikan karakter di tingkat Taman Kanak-kanak juga sangat terkait dengan manajemen atau pengelolaan sekolah. Pengelolaan sekolah dimaksudkan dengan bagaimana pendidikan karakter direncanakan, dilaksanakan, dan dikendalikan dalam kegiatan-kegiatan disekolah yang meliputi; nilai-nilai yang perlu ditanamkan, muatan kurikulum, pendidikan dan tenaga pendidikan dan komponen terkait lainnya seperti hubungan sekolah dengan wali murid sebagai pendidik anak diluar jam sekolah dengan menggunakan perantara buku penghubung.

Dalam pelaksanaan praktik pendidikan yang ada di Indonesia baik dalam setara pendidikan dasar, menengah maupun tingkat atas, apabila dilihat dari standar nasional pendidikan yang menjadi acuan pengembangan kurikulum 2013, serta implementasi dan penilaian di sekolah, tujuan pembelajaran di tingkat Taman Kanak-kanak sebenarnya sudah dapat dicapai dengan baik melalui metode pembelajaran yang beraneka ragam dan berkembang sesuai dengan tingkat perkembangan anak. Termasuk pendidikan karakterpun sudah mulai dikenalkan dan dimasukkan dalam metode pembelajaran yang ada di tingkat Taman Kanak-kanak. Permasalahannya, pendidikan karakter di tingkat Taman Kanak-kanak masih dalam tingkatan pengenalan dan pembiasaan ketika jam pembelajaran di sekolah, dan belum pada tingkatan implementasi dan tindakan nyata dalam kehidupan sehari-hari baik di rumah maupun dalam aktiftas diluar jam pembelajaran di sekolah.

Guru di Taman Kanak-Kanak Negeri Pembina Surakarta dalam mengajarkan pendidikan karakter budaya Jawa kepada siswanya, mereka tidak hanya memberikan konsep kepada para siswa tentang karakter apa dan mana yang dianggap sesuai oleh masyarakat, tetapi juga berusaha untuk menjalankannya. Bagi guru, pituduh (wejangan) tidak akan berhasil jika hanya diucapkan saja, tanpa dilaksanakan, dan ini sesuai dengan adagium yang muncul dengan istilah "gedhang awoh pakel, ngomong gampang ngelakone angel" (ibarat pisang berbuah mangga, bicara mudah tetapi menjalankannya susah), atau istilah lainnya "gajah 
diblangkoni, bisa kojah ora bisa nglakoni" (seperti gajah yang diberi blangkon, hanya bicara tidak pernah melaksanakan apa yang diucapkannya).

Sementara itu, terkait dengan peran guru dalam menerapkan pendidikan karakter berbasis budaya Jawa pada anak usia dini di Taman Kanak-Kanak Negeri Pembina Surakarta yang merupakan program unggulan, tentunya akan disesuaikan dengan budaya Jawa, tentang unggah-ungguh/tata krama yang dapat dimasukkan dengan nilai-nilai karakter yang ada. Dalam teori perkembangan, anak akan tumbuh dan berkembang dengan baik tidak saja cukup mengandalkan potensi yang dibawanya secara genetik akan tetapi juga sangat ditunjang oleh faktor lain yaitu lingkungannya sebagaimana dinyatakan oleh John Lock (1632-1704) melalui teori empirismenya yang beranggapan bahwa "manusia lahir dalam keadaan tabularasa, putih bersih bagaikan kertas yang belum ditulisi. Lingkunganlah yang membentuk seseorang menjadi manusia seperti dia pada waktu dewasa" (Irwanto, CS dalam Sofiah, 2012: 212).

Tujuan penelitian ini adalah: 1) Mendeskripsikan pengelolaan pendidikan karakter berbasis budaya Jawa di TK Negeri Pembina Surakarta. 2) Mendeskripsikan faktor pendukung dan penghambat pengelolaan pendidikan karakter berbasis budaya Jawa di TK Negeri Pembina Surakarta.

\section{METODE PENELITIAN}

Jenis penelitian ini adalah penelitian deskriptif. Penelitian diskriptif adalah penelitian yang dilakukan untuk mengetahui nilai variabel mandiri, baik satu variabel atau lebih (independen) tanpa membuat perbandingan, atau menghubungkan dengan variabel yang lain (Sugiyono, 2012: 115). Desain yang digunakan dalam penelitian ini adalah desain penelitian deskriptif kualitatif, yaitu penelitian yang berlandaskan pada filsafat postpositivisme, digunakan untuk meneliti pada kondisi objek yang alamiah, dimana peneliti adalah sebagai instrumen kunci, teknik pengumpulan data dilakukan secara triangulasi (gabungan), analisis data bersifat induktif/kualitatif dan hasil penelitian kualitatif lebih menekankan makna dari pada generalisasi (Sugiyono, 2010: 9). Deskripsi dalam penelitian ini mengenai pengelolaan pendidikan karakter berbasis budaya Jawa di TK Negeri Pembina Surakarta.

Pelaksanaan penelitian ini adalah di TK Negeri Pembina Surakarta. TK Negeri Pembina Surakarta saat ini memiliki jumlah Kelompok Belajar sebanyak 6 Kelompok Belajar dan 1 Kelompok Bermain. Adapun jumlah tenaga pendidik sebanyak 11 orang, 1 kepala sekolah dan 8 orang karyawan. Validitas data yang digunakan dalam penelitian ini adalah triangulasi sumber dan triangulasi teknik. Teknik analisa data yang digunakan dalam penelitian tersebut adalah model analisis interaktif (model saling terjalin). Dalam model analisis interaktif, tiga komponen yakni reduksi data, sajian data dan penarikan kesimpulan dilakukan berbentuk interaksi dengan proses pengumpulan data sebagai proses siklus.

\section{HASIL DAN PEMBAHASAN}

\section{Pengelolaan Pendidikan Karakter Berbasis Budaya Jawa di TK Negeri Pembina Surakarta}

Penyelenggaraan pendidikan berbasis budaya Jawa merupakan salah satu cara untuk menyampaikan muatan budaya Jawa melalui pendidik anak-anak. Melalui pendidikan ini dapat disampikan berbagai unsur, nilai dan budi pekerti serta pengembangan minat dan bakat 
peserta didik dalam keterampilan seni budaya Jawa. Konsep pendidikan berbasi budaya Jawa ini mendukung dalam pembentukan karakter peserta didik melalui peningkatan kemampuan pengetahuan yang diiringi penanaman budi pekerti dan nilai-nilai budaya Jawa. Selain itu, pendidikan ini juga salah satu wujud pelestarian budaya Jawa melalui pengenalan sejak dini terhadap peserta didik.

TK Negeri Pembina Surakarta menunjukkan implementasi pendidikan berbasis budaya melalui berbagai komponen pendidikan. Pengertian pendidikan secara khusus menurut Dewantara (2011:13) adalah salah satu usaha untuk memberian segala nilai-nilai kebatinan yang ada dalam hidup rakyat yang berbudaya kepada setiap generasi, tidak hanya berupa pemeliharaan akan tetapi juga dapat dimaksud memajukan serta mengembangkan kebudayaan menuju kearah keluhuran hidup manusia. Hal tersebut menununjukkan bahwa seharusnya pendidikan tidak hanya memelihara kebudayaan tetapi bahkan memajukan dan mengembangkan tanpa meninggalkan karakteristik budaya itu sendiri. Inilah yang coba direalisasikan oleh TK Negeri Pembina Surakarta dalam pendidikannya. Unsur-unsur budaya Jawa sebagai kearifan budaya lokal digunakan untuk memenuhi kebutuhan peserta didik sesuai kodrat alamnya selain dalam hal pengetahuan umum.

TK Negeri Pembina Surakarta ini melaksanakan sistem among sebagai sistem pendidikan. Sistem among merupakan pencerminan dari tut wuri handayani pada semboyan pendidikan Ki Hadjar Dewantara. Seperti pengertian sistem among pada pasal 12 Piagam dan Peraturan Besar Persatuan Taman Siswa (Fudyartanta, 1986: 12) yang dirumuskan sebagai suatu sistem pendidikan yang berjiwa kekeluargaan dan bersendikan dua dasar, yaitu: (1) Kodrat Alam, sebagai syarat untuk mencapai kemajuan dengan secepat-cepatnya dan sebaik-baiknya; dan (2) Kemerdekaan, sebagai syarat untuk menghidupkan dan menggerakkan kekuatan lahir batin peseta didik agar dapat memiliki pribadi yang kuat dan dapat berfikir serta bertindak merdeka. Sistem tersebut menurut berlakunya juga disebut sistem "Tutwuri Handayani”.

Sekolah ini menerapkan sistem dimana peran pendidik sebagai pengawas atau pengamat memberikan pembelajaran tanpa paksaan dan membiarkan peserta didik berkembang sebagaimana mestinya sesuai jalur yang benar. Hal ini seperti yang dikemukakan oleh Dewantara (2011: 13) bahwa pendidikan Tamansiswa tidak memakai syarat paksaan. Opvoeding atau paedagogiek semaksud dengan pengertian momong, among dan ngemong. Itulah yang digunakan sebagai dasar pendidikan Tamansiswa. Caranya tidaklah memaksa walaupun hanya sekedar memimpin kadang juga tidak perlu. Kita hanya perlu mencampuri kehidupan anak kalau berada di jalan yang salah. Bahasa momong, among dan ngemong merupakan istilah Jawa yang menggambarkan cara mendidik anak-anak di masyarakat Jawa. Sehingga sistem among juga merupakan wujud budaya pendidikan masyarakat Jawa.

Di sekolah ini pendidik menjalankan perannya sebagai pemimpin ketika menyampaikan pembelajaran, sebagai teman yang mampu memberikan motivasi dan memposisikan diri sebagai pengamat yang mendukung ketika peserta didik mengaplikasikan ilmu yang diperoleh. Hal ini senada dengan pernyataan Purwanto (2011: 63) mengungkapkan bahwa dalam sistem among setiap pamong atau pendidik sebagai seorang pemimpin dalam proses pendidikan diwajibkan bersikap 1) Ing Ngarsa Sung Tuladha yang artinya jika pendidik sedang berada di depan maka hendaknya memberikan contoh teladan yang baik terhadap peserta didiknya, 2) Ing Madya Mangun Karsa yang berarti jika pendidik sedang berada di tengah-tengah peserta 